\title{
Reversible cerebral vasoconstriction syndrome following carotid stenting
}

Figure Cerebral angiogram
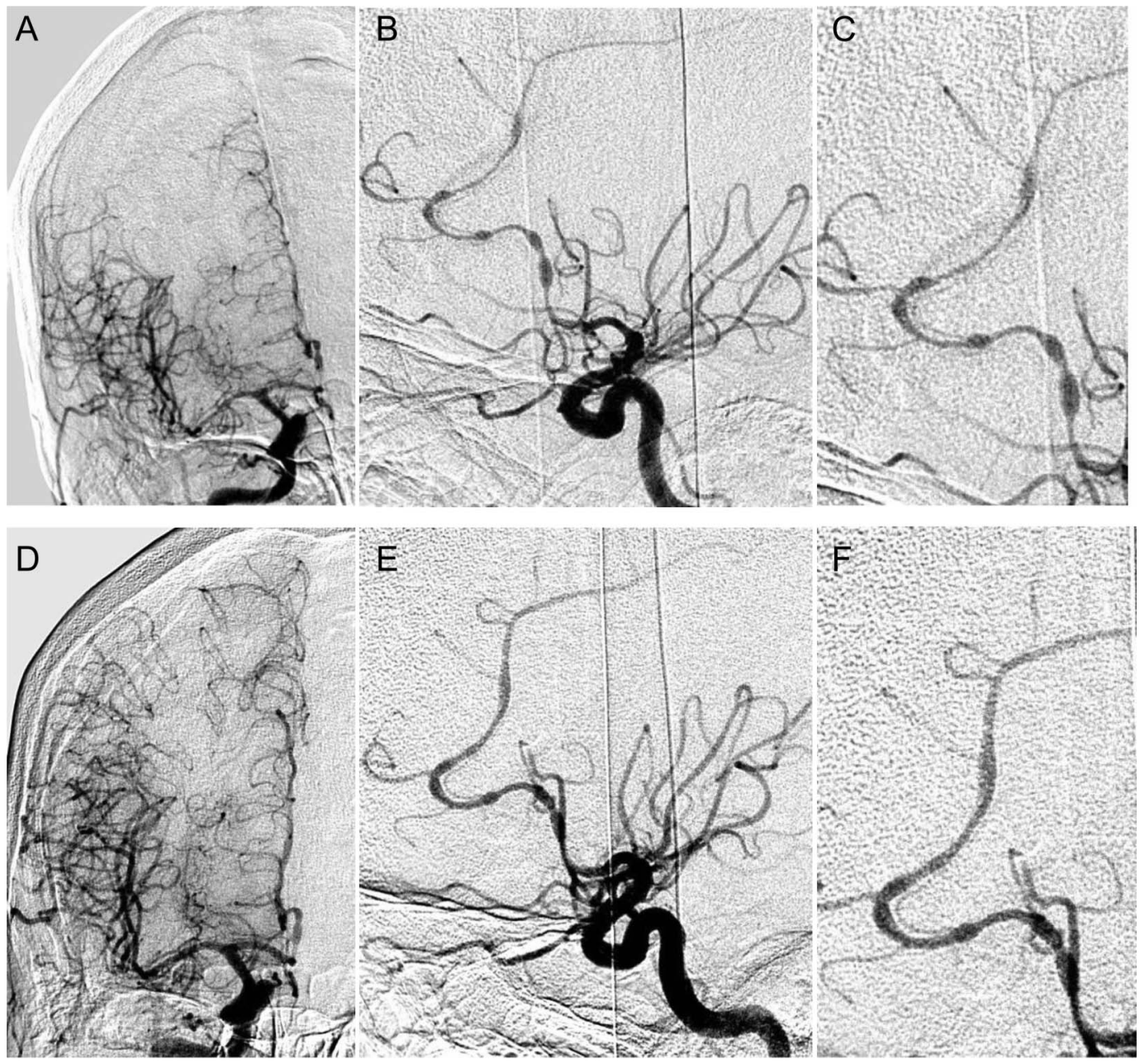

Catheter-based angiogram shows right anterior cerebral and right middle cerebral artery irregularities (A-C), which markedly improved after administration of intra-arterial verapamil (D-F).

A 60-year-old woman on venlafaxine presented with headache and left-sided weakness 1 month after undergoing right common carotid artery stenting. Catheter-based angiogram identified new irregularities of the right anterior cerebral and right middle cerebral artery (figure, A-C). Investigations for vasculitis, including CSF studies, were unremarkable. The vessel irregularities and symptoms improved after administration of intraarterial verapamil (figure, D-F). Unilateral reversible cerebral vasoconstriction syndrome has previously been described after carotid endarterectomy. The mechanism is unclear; however, it may be due to disturbance of cerebral autoregulation. ${ }^{1,2}$ Concomitant use of a serotonin and norepinephrine reuptake inhibitor may have been a predisposing factor.

Amin Aghaebrahim, MD, Ashutosh P. Jadhav, MD, PhD, Yumna Saeed, MD, Ruta Totoraitis, MD, Brian T. Jankowitz, MD, Tudor G. Jovin, MD, Bradley J. Molyneaux, MD, PhD

From the University of Pittsburgh Medical Center, Pittsburgh, PA. 
Author contributions: Dr. Aghaebrahim: drafting/revising the manuscript and analysis and interpretation of data. Dr. Jadhav: revising the manuscript and analysis and interpretation of data. Dr. Saeed: analysis and interpretation of data. Dr. Totoraitis: analysis and interpretation of data. Dr. Jankowitz: analysis and interpretation of data. Dr. Jovin: analysis and interpretation of data. Dr. Molyneaux: revising the manuscript and analysis and interpretation of data.

Study funding: No targeted funding reported.

Disclosure: The authors report no disclosures relevant to the manuscript. Go to Neurology.org for full disclosures.

Correspondence to Dr. Molyneaux: moly@pitt.edu

1. Wu TY, Frith RW, Barber PA. Reversible cerebral vasoconstriction following carotid endarterectomy. J Clin Neurosci 2011;18: $1725-1728$.

2. Ducros A. Reversible cerebral vasoconstriction syndrome. Lancet Neurol 2012;11:906-917.

\section{Subspecialty Alerts by E-mail!}

Customize your online journal experience by signing up for e-mail alerts related to your subspecialty or area of interest. Access this free service by visiting http://www.neurology.org/site/subscriptions/etoc.xhtml or click on the "E-mail Alerts" link on the home page. An extensive list of subspecialties, methods, and study design choices will be available for you to choose from-allowing you priority alerts to cutting-edge research in your field!

\section{You're Committed to Continually Expanding Your Knowledge}

NeuroSAETM is committed to helping you. The Sixth Edition of the AAN's convenient online selfassessment examination is now available, featuring 150 questions and 8 self-assessment CME credits upon successful completion to help meet ABPN MOC requirements.

See all the available NeuroSAE versions and purchase the exam today at AAN.com/view/neuroSAE.

\section{Save These Dates for AAN CME Opportunities!}

Mark these dates on your calendar for exciting continuing education conferences by the American Academy of Neurology. Learn more at AAN.com/conferences.

\section{AAN Fall Conference}

- October 31-November 2, 2014, Las Vegas, NV, The Cosmopolitan of Las Vegas AAN Annual Meeting

- April 18-25, 2015, Washington, DC, Walter E. Washington Convention Center 


\section{Neurology}

\section{Reversible cerebral vasoconstriction syndrome following carotid stenting}

Amin Aghaebrahim, Ashutosh P. Jadhav, Yumna Saeed, et al. Neurology 2014;83;570-571

DOI 10.1212/WNL.0000000000000677

This information is current as of August 4, 2014

Updated Information \&
Services
References
Citations
Subspecialty Collections
Permissions \& Licensing
Reprints

\section{Updated Information \&}

References

\section{Citations}

\section{Subspecialty Collections}

Reprints including high resolution figures, can be found at: http://n.neurology.org/content/83/6/570.full

This article cites 2 articles, 0 of which you can access for free at: http://n.neurology.org/content/83/6/570.full\#ref-list-1

This article has been cited by 2 HighWire-hosted articles: http://n.neurology.org/content/83/6/570.full\#\#otherarticles

This article, along with others on similar topics, appears in the following collection(s):

All Cerebrovascular disease/Stroke

http://n.neurology.org/cgi/collection/all_cerebrovascular_disease_strok e

Infarction

http://n.neurology.org/cgi/collection/infarction

Information about reproducing this article in parts (figures,tables) or in its entirety can be found online at:

http://www.neurology.org/about/about_the_journal\#permissions

Information about ordering reprints can be found online:

http://n.neurology.org/subscribers/advertise

Neurology ${ }^{\circledR}$ is the official journal of the American Academy of Neurology. Published continuously since 1951, it is now a weekly with 48 issues per year. Copyright () 2014 American Academy of Neurology. All rights reserved. Print ISSN: 0028-3878. Online ISSN: 1526-632X.

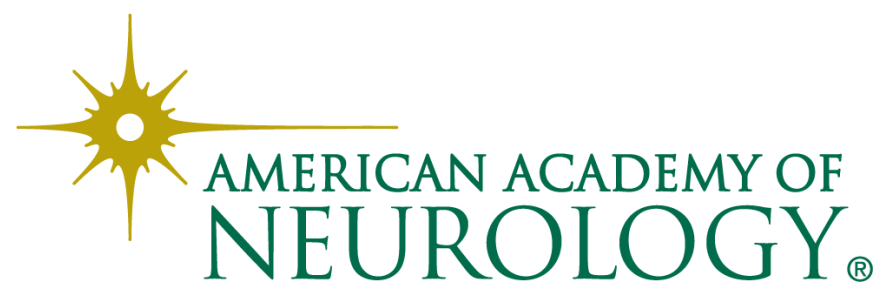

